\title{
+Research Paper \\ The Effectiveness of Emotional Self-Control on Students' Academic Vitality and Academic Performance
}

Ciroos Soorgi ${ }^{1}$, Mohamad-Hassan Ghanifar ${ }^{* 2}$, Mohammad Reza Asadi Yoonesi ${ }^{3}$, Qasem Ahi $^{2}$

1. Ph.D. Student of Educational Psychology, Birjand Branch, Islamic Azad University, Birjand, Iran

2. Assistant Professor, Department of Psychology, Birjand Branch, Islamic Azad University, Birjand, Iran

3. Assistant Professor, Department of Psychology, University of Birjand, Birjand, Iran

Citation: Soorgi C, Ghanifar M, Asadi Yoonesi MR, Ahi Q. The effectiveness of emotional self-control on students' academic vitality and academic performance. Quarterly Journal of Child Mental Health. 2020; 7(3): 40-52.

\section{http://dx.doi.org/10.52547/jcmh.7.3.5}

\section{A R T I C L E I N F O}

\section{Keywords: \\ Emotional self-control, academic vitality, academic performance, students}

Received: 4 Jun 2020

Accepted: 21 Sep 2020

Available: 9 Dec 2020

\section{A B S T R A C T}

Background and Purpose: Over the years, academic performance has been widely considered as one of the indicators of assessing the students' learning and the quality of education. During their academic life, students face different challenges, obstacles and stresses which may threaten their academic performance and academic vitality. Therefore, this study was done to investigate the effectiveness of emotional self-control training on the academic vitality and academic performance of students.

Method: The present study was a quasi-experimental study with control group pretest- posttest design including the follow-up stage. The study population included all the male students studying at the first cycle of the secondary school in Birjand city in the academic year of 2019-2020. Among which a sample of 40 students were selected by purposive sampling and then assigned randomly to the experimental or the control group (20 per group). The experimental group received eigth 60 -min sessions of emotional self-control; whereas no training was done for the control group. The research tools included Questionnare of Academic Vitality (Dehghanzadeh and Hosseinchari, 2012), Academic Performance Questionnaire (Dortaj, 2004) and Self-control Scale (Tanjeny et al., 2004). Data were analyzed by repeated measures ANOVA at the significance level of $\alpha=0.05$.

Results: Results of data analysis showed that emotional self-control training was effective on academic vitality $(\mathrm{p}<0.01)$ and academic performance and its components (self-efficacy, emotional effects, planning, lack of outcome control and motivation) $(\mathrm{p}<0.01)$. The findings persisted in the follow-up period ( $\mathrm{p}<0.01)$.

Conclusion: Based on the results of this study, it can be concluded that emotional self-control training can improve the skills related to resilence and adjustment and prevent the inappropriate emotions in students which in turn can increase the academic vitality and academic performance in them.

\footnotetext{
* Corresponding author: Mohamad-Hassan Ghanifar, Assistant Professor, Department of Psychology, Birjand Branch, Islamic Azad University, Birjand, Iran.

E-mail addresses: Ghanifar@iaubir.ac.ir
} 


\section{اثربخشى خودمهار Fرى هيجانى بر سرزند}

\section{سيروس سور كى'، محمدحسن غنى فر "، محمدرضا اسدى يونسى" ، قاسم آهى}

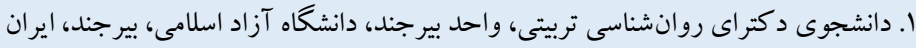

r. استاديار گروه روانشناسى، واحد بيرجند، دانشكاه آزاد اسلامى، بير جند، ايران

r. استاديار، گروه روانشناسى، دانشگاه بير جند، بيرجند، ايران

\section{$\Delta \mathrm{Wr}_{*}$}

زمينه و هدف: عملكرد تحصيلى به عنوان يكى از شاخصهاى ارزيابى يادگيرى دانش آموزان و كيفيت آموزش طى سالهاى متمادى به طور گسترده مورد توجه متخصصان قرارگرفته است. دانش آموزان در زندگى با انواع كشاكثها، موانع و فشارهاى ويزه دوران تحصيل روبهرو مى شوند كه تهديدى براى عملكرد تحصيلى و شادابى آنها است. بدين ترتيب مطالعه حاضر با هدف تعيين اثربخشى آموزش خودمهار گرى هيجانى بر سرزندگى تحصيلى و عملكرد تحصيلى دانش آموزان انجام شد. روش: يُزوهش حاضر نيمه آزمايشى با طرح بيش آزمون- بِ آزمون با گروه گَواه و مرحله بيگيرى بود. از جامعه آمارى كه شامل تمامى

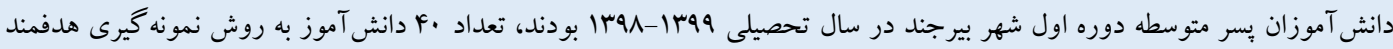

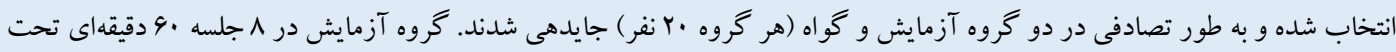

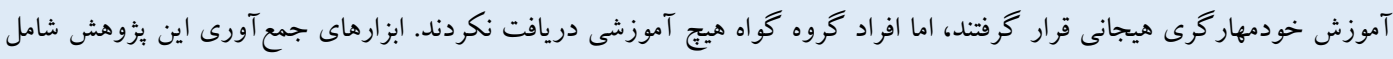

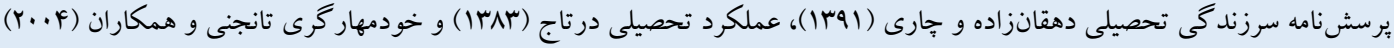

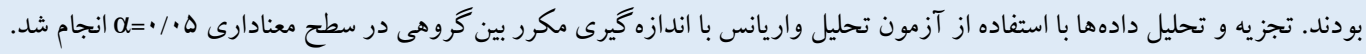
يافتها: نتايج تحليل دادها نشان داد كه آموزش خودمهارگرى هيجانى بر سرزند

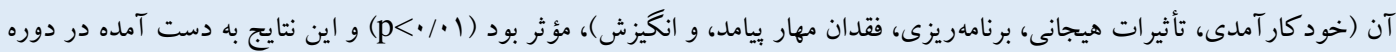

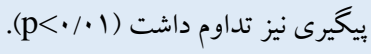

نتيجه كيرى: بر اساس نتايج اين مطالعه مى توان نتيجه گيرى كرد كه آموزش خودمهار گرى هيجانى به دانش آموزان باعث بهبود مهارت هاى مربوط به تاب آورى و سازش يافتكى و ييشخيرى از بروز هيجان نامناسب شده و در نتيجه سرزند ئى و عملكرد تحصيلى آنها، افزايش بيدا
مشخصات مقاله

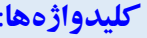

خودمهار گرى هيجانى،

سرزندگى تحصيلى،

عملكرد تحصيلى،

$$
\text { دانش آموزان }
$$

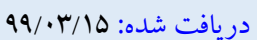

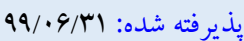

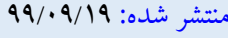

* نويسنده مسئول: استاديار گروه روانشناسى، واحد بيرجند، دانشگاه آزاد اسلامى، بيرجند، ايران.

رايانامه: Ghanifar@iaubir.ac.ir 
موقعيـتهاى روزمره و عادى تحصـيلى اتفاق مىافتد (V). دانش آموزان

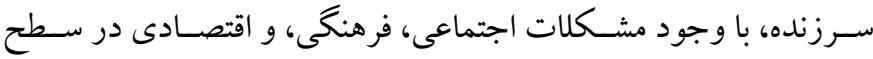

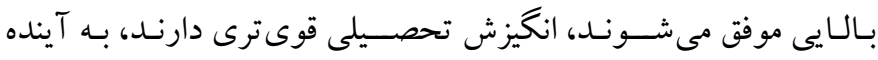

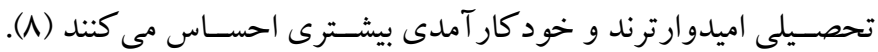
ويز گى هاى شــخصـيتى همجِون خودينداشـــت مثبت، اجتماعى بودن،

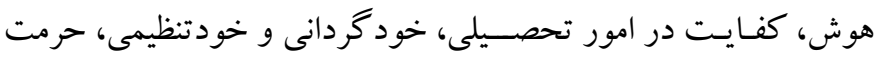
خود، ارتباط خوب، سـلامت روانى و جسمانى، و مهارتهاى حل مسئله

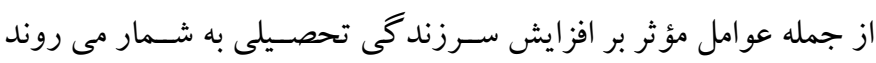

امـروزه مــاخلـات و آموزشهــاى زيـادى براى افزايش عملكرد

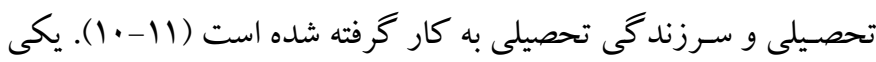

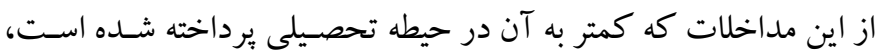

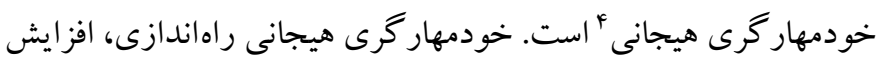

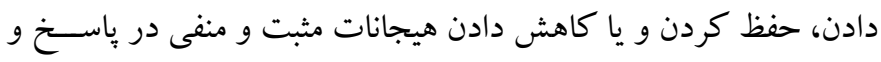

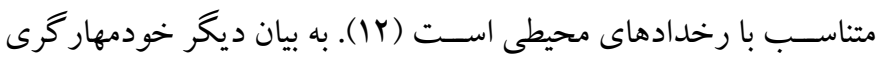
هيجانى فرايندى منحصر به فرد و يكانه براى تعديل تجارب هيجانى خود

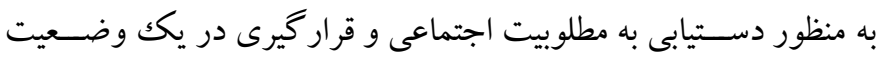

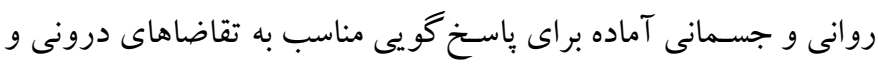

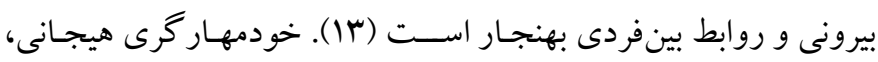

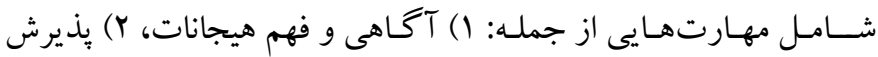
هيجانات، ץ) توانايى براى مهار رفتارهاى تكانشى و رفتار نمودن بر اساس ته اهداف مورد نظر در زمان بروز هيجانات منفى، و F) تو انايى براى استفاده

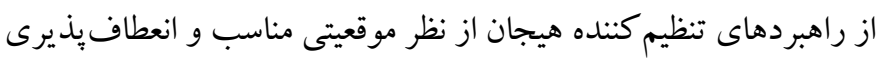
در تعديل باسـخ هاى هيجانى بر اسـاس اهداف فردى و تقاضاى موقعيتى

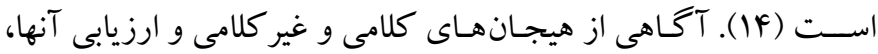
مى تواند موجب تمايل به باسـخدهى ارادى در جهت تعديل و استفاده از

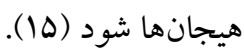
خودمهار گرى ويز گى مهم و قابل توجهى اســت كه به افراد امكان

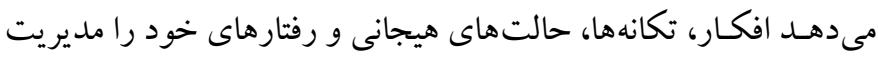
كنند؛ به عبارتى قدرت تنظيم احساسات موجب افزايش ظرفيت شخصى
مقدمه

دانش آموزان به عنوان ركن اسـاسـى نظام آموزشـى، در دسـت يابى به

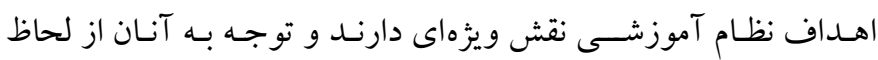

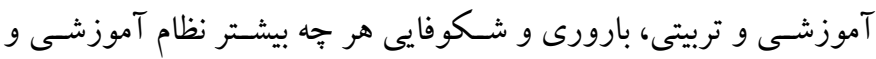

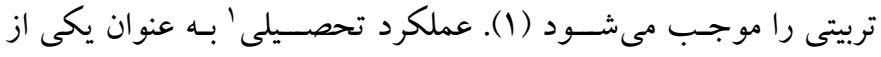

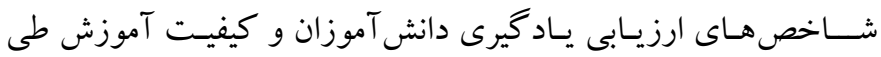

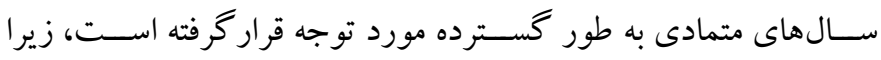

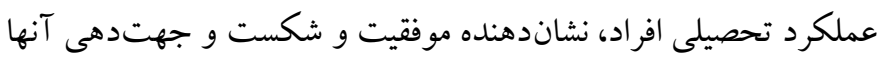

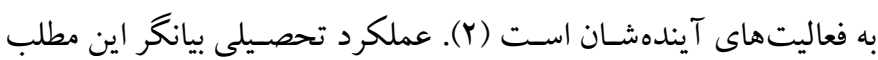

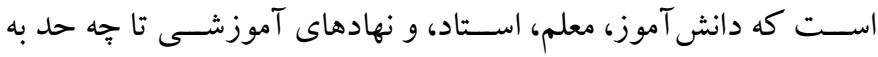

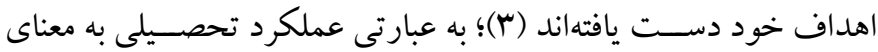

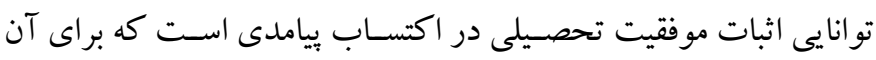

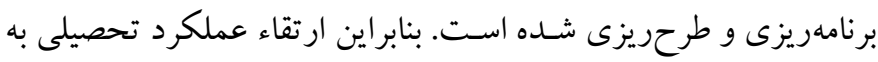

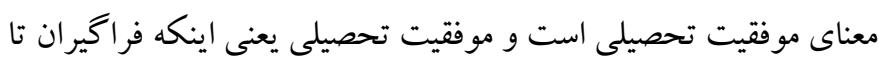

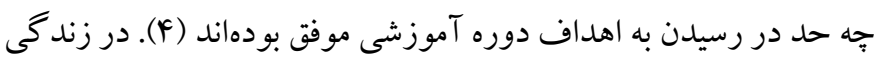
روزانه تحصيلى دانش آموزان با انواع كشاكش ها، موانع و فشارهاى ويزه بـ دونه

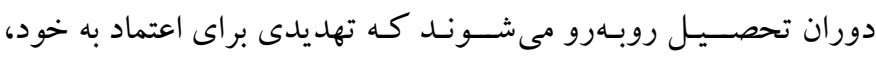

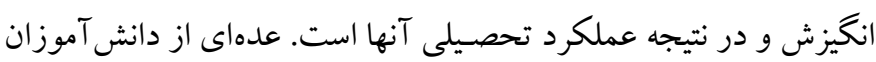

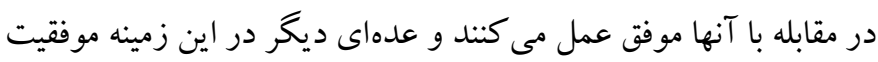

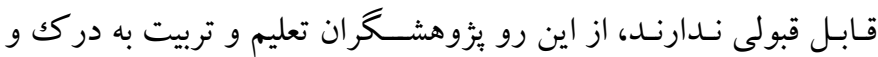

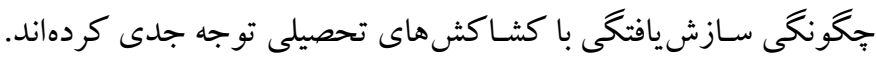

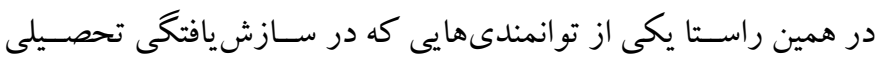

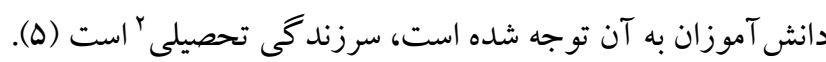

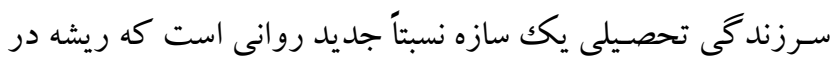

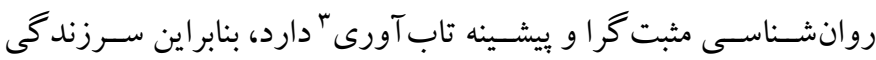

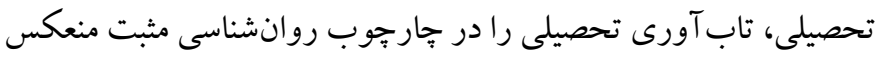

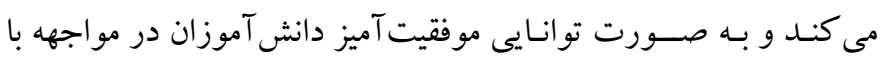

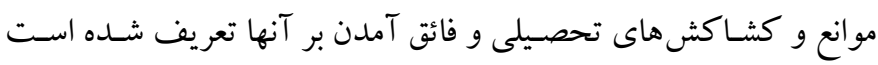

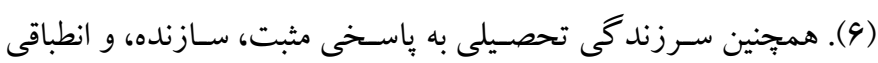

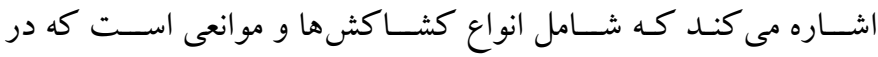

1. Academic performance

2. Academic vitality 
خودمهارگرى هيجانى بر ســرزندگى تحصـيلى و عملكرد تحصـيلى

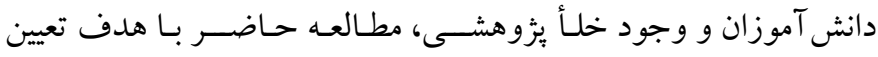
اثربخشـى آموزش خودمهار گرى هيجانى بر ســـرزند

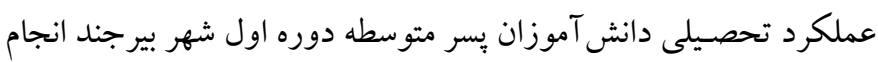
الف) طرح يزوهش و شر كت كنند كان: يزوهش حاضـر نيمه آزمايشى

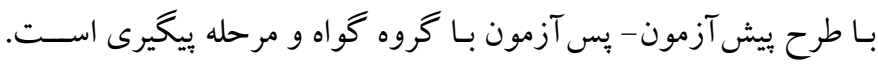

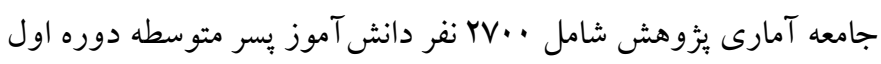

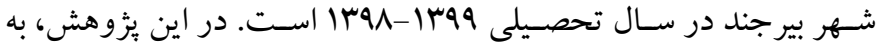
روش نمونـه كيرى هدفمند، تعداد •F دانش آموز (حداقل حجم نمونه در

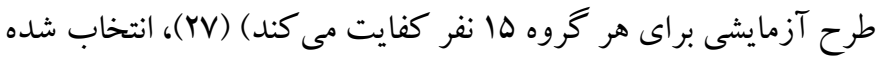

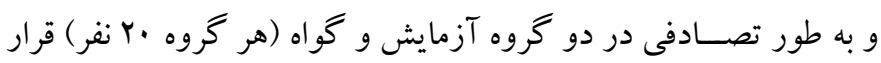

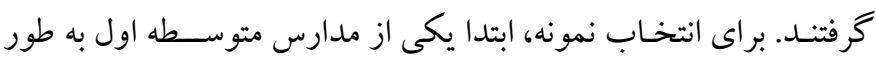

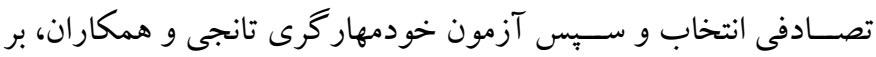

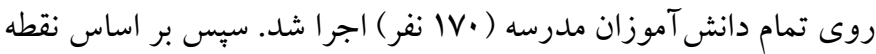

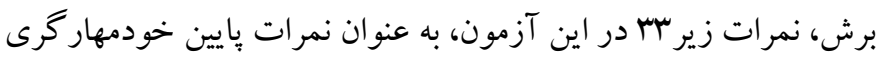

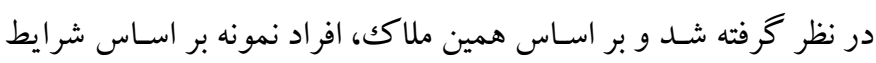

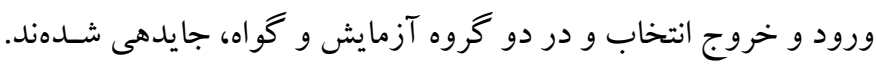

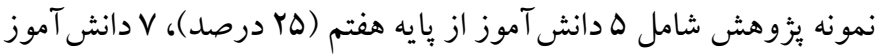

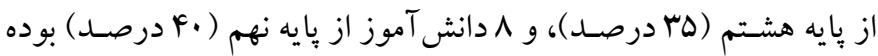

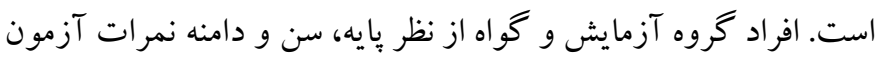

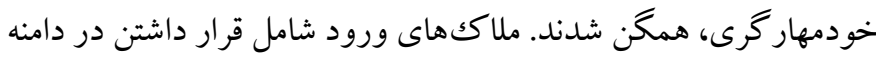

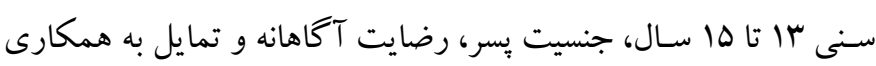
دانش آموز، والدين و مديران مدارس بوده اســت. ملاككهاى خروج نيز

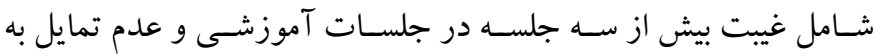
همكارى در جلسات آموزشى بود.
براى تسـكين دادن خود، درك كردن اضـطرابهـا، افسـردگى، يـا بى حو صـلكى هاى متداول مى شـود (19). افر ادى كه مهارتهاى هيجانى

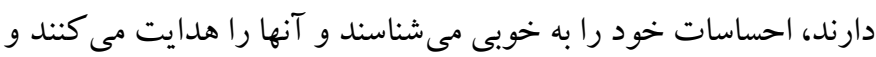

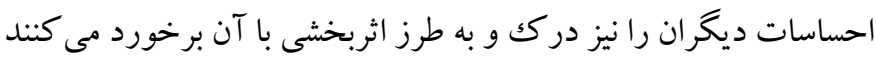

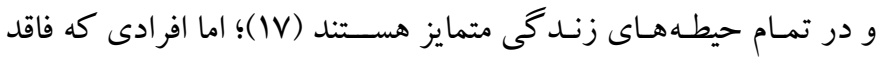

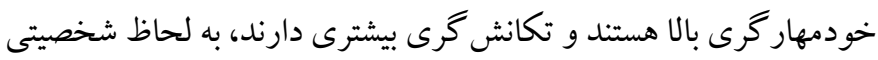

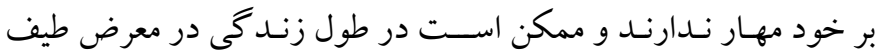

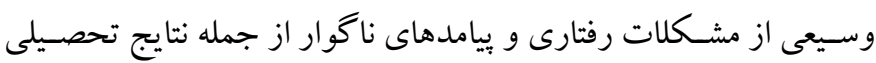

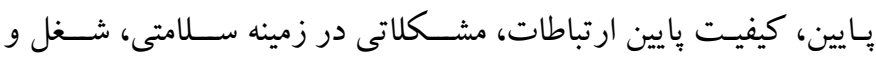

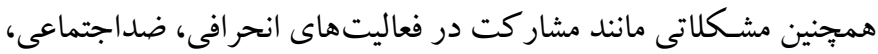

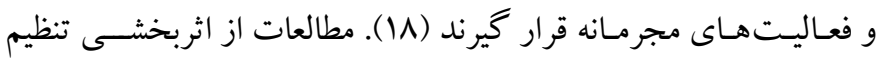
هيجـان بر افزايش معنـاى تحصـيلى و ســازش يافتخى تحصـيلى (19)،

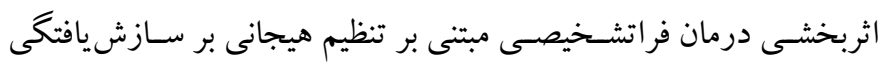

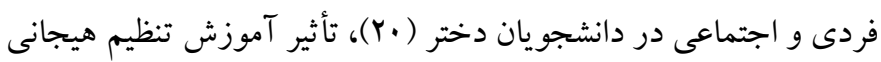

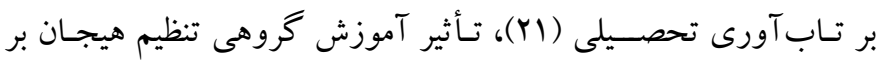

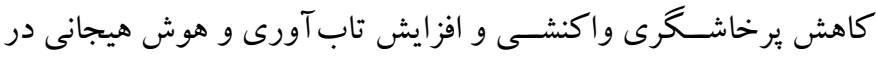

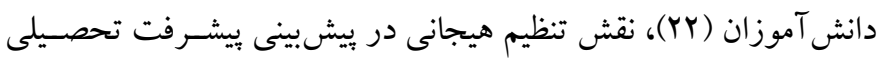

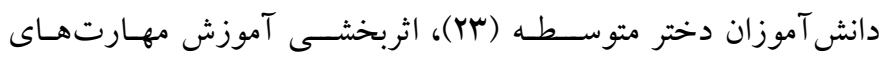

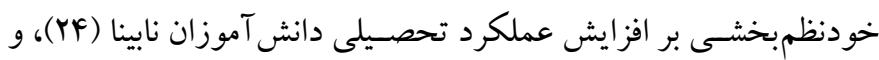

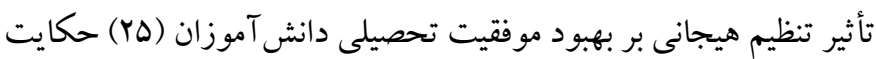

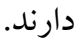

در مجموع از آنجا كه زندگى تحصسيلى، يكى از مهمترين دورههاى

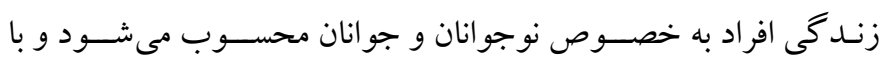

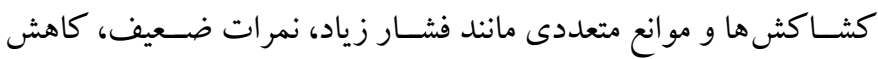

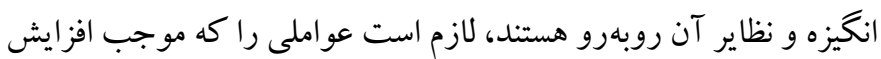

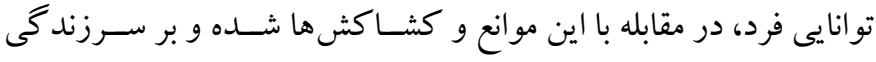

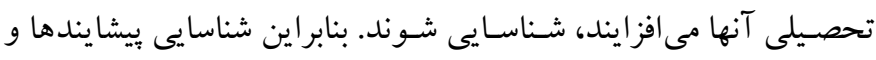

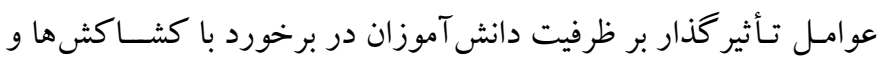

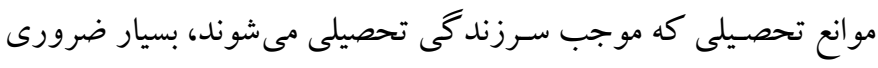

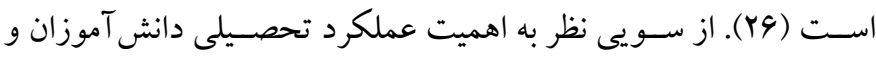
نقش تنظيم هيجانات در بهداشـت روانى، تحصـيلى، و اجتماعى آنان و

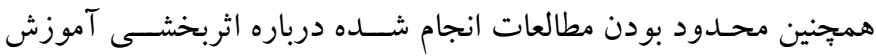


و فرحبخش اعتبار كل يرسشنامه به روش آلفاى كرونباخ، AF/ • گزارش

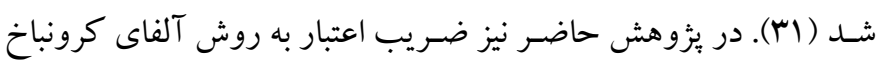

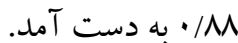

r. برسشنامه خودمهاركرى " اين برسشنامه توسط تانجنى، بوميستر و بون

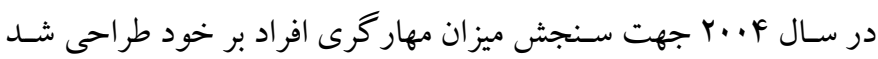

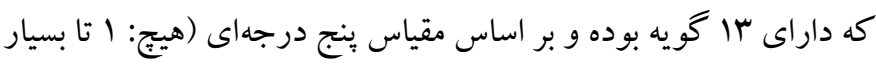

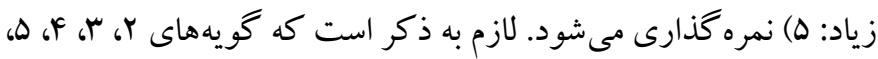

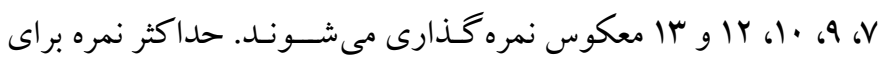
يرسشنامه 90 و حداقل سا است. افرادى كه نمره سم و بالاتر كسب كنند،

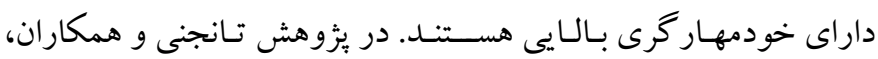

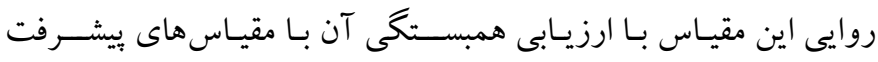

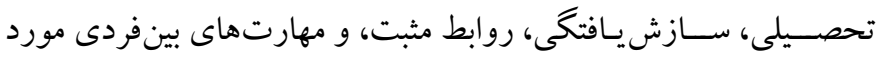

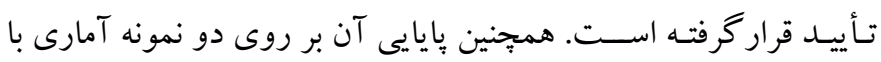

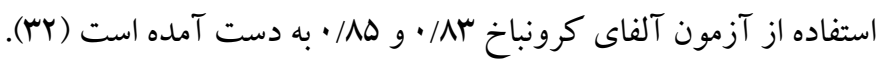

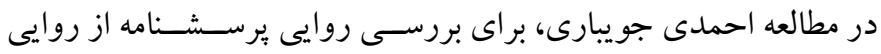

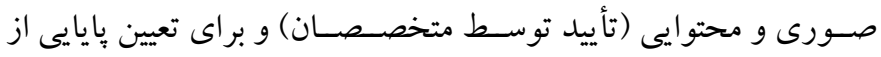

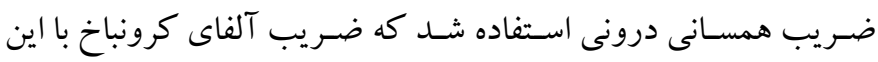

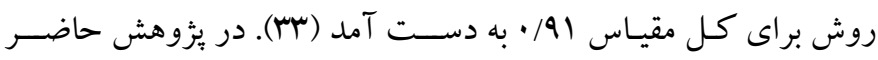
ضريب اعتبار به روش آلفاى كرونباخ، شه/ • به دست آمد.

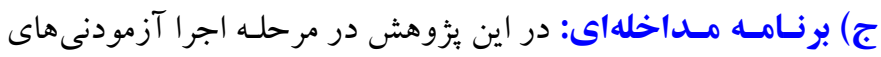

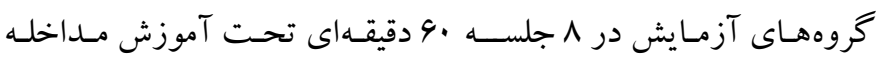
آموزش تنظيم هيجان مبتنى بر مدل گراس (MF) كه روايى آن در مطالعه

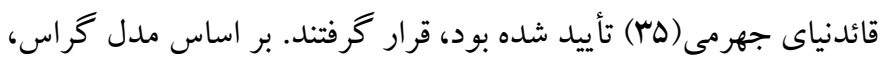

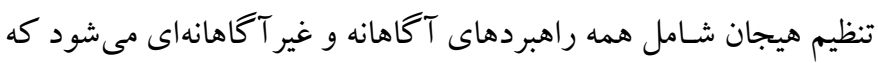
براى افزايش، حفظ و كاهش مؤلفه هاى هيجانى، رفتارى و شناختى يكك

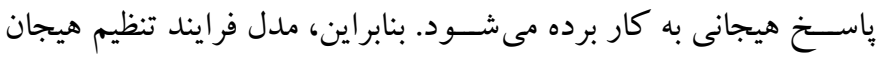

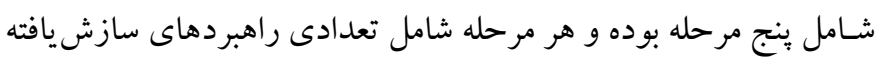

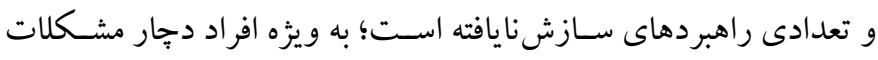
هيجانى بيشـتر از راهبردهاى سازشنايافته استفاده مى كنند (مانند نشخوار

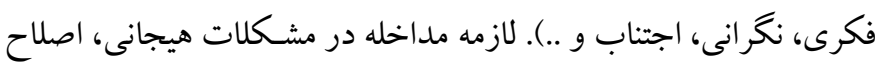

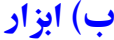
ا . يرسـشنامه سـززنلكى تحصسيلى ': اين برسشنامه توسط دهقانىزاده و

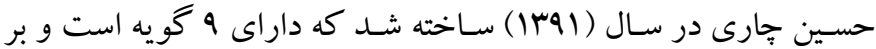
روى مقيـاس ينجدرجهاى ليكرت از كاملاً مخالف ( (1) تا كاملاً موافق (ه) نمره گذارى مى شـود. دامنه نمرات بين ه تا لها اسـت. دانش آموزانى كه در اين مقيـاس نمره سب و بـالـاتر كســب كنتـد، بـه منزله برخوردارى از ســرزندكى بيشـتر اسـت (YN). در مطالعه دهقانى زاده و حسـين جارى ضرايب آلفاى كرونباخ برابر با • •// • و ضريب باز آزمايى برابر با سل/ • به دسـت آمد. همبجنين دامنه همبستكى سؤالها حاكى از همسانى درونى و

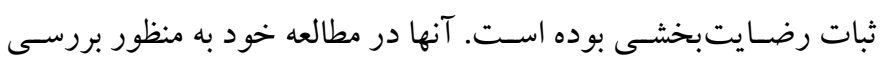
سـاختار عاملى برسـشـنامه، از تحليل مؤلفههاى اصـلى با جر خش متعامد واريماكس استفاده كردند كه در مجموع Q گويه يرسسشنامه، WV درصد

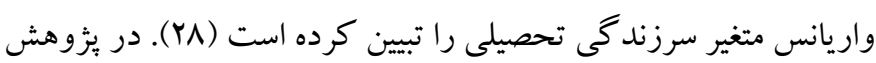
مرادى و جر اغى ضريب اعتبار يرسشنامه به روش آلفاى كرونباخ ·V/ • به دســ آمد (Y9). در بثزوهش حاضـر نيز ضــريب اعتبار به روش آلفاى كرونباخ V9/ • به دست آمد.

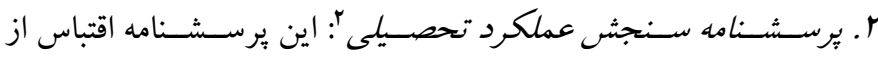

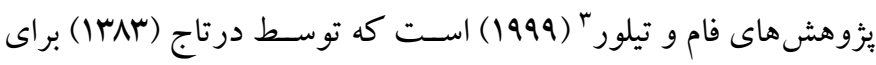
جامعه ايرانى سـاخته و اعتباريايى شده است. يرسشنامه عملكرد تحصيلى

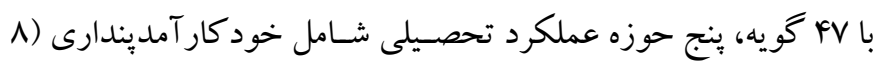

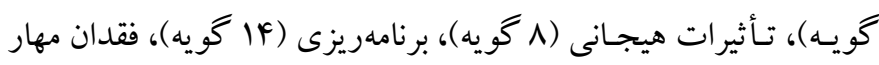

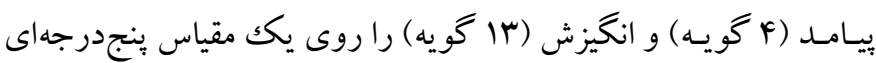

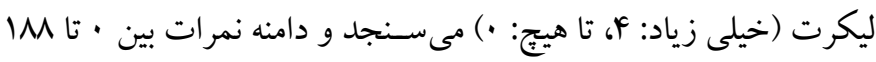
اسـت. دانش آموزانى كه در اين مقياس نمره هو يا بيشـتر كسـب كنند، از عملكرد تحصيلى بالايى برخورداند (•r). در يزوهش درتاج روايى محتوا با استفاده از نظر استادان متخصص مورد تأييد قرار گرفت و روايى سازه به روش تحليل عاملى، تأييد شـد. ضرايب آلفاى كرونباخ جهت محاسبه اعتبار برسـشنامه براى ابعاد خود كار آمدى، برنامهريزى، تأثيرات هيجانى،

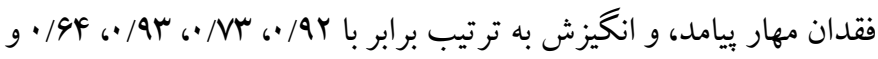

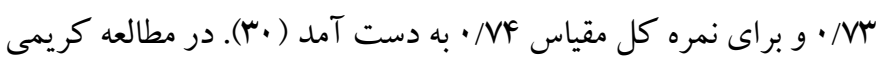


شـناختى، و تعديل پِاســخ (YY). خلاصسه جلسـات درمانى آموزش تنظيم هيجانى مطابق جدول ا انجام شد.
يـا حذف راهبردهاى ســازشنايافته و آموزش راهبردهاى ســازش يافته

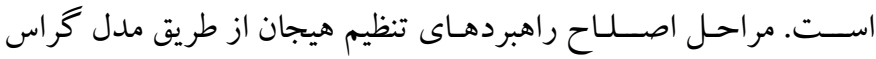

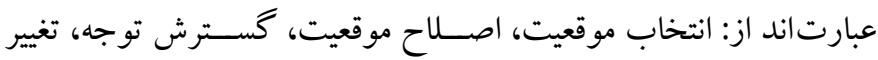

جدول ا: خلاصه جلسات مداخله آموزش تنظيم هيجان مبتنى بر مدل كراس

\begin{tabular}{|c|c|c|}
\hline محتوا & 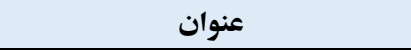 & جلسه \\
\hline 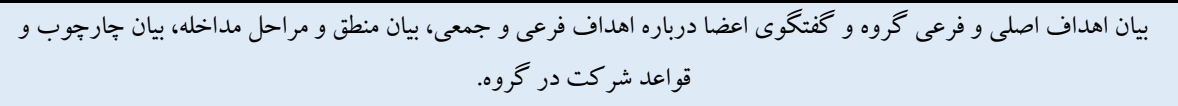 & آشنايى و برقرارى ارتباط اعضا با يكديخر & 1 \\
\hline ارائه آموزش هيجانى: () هيجان بهنجار و هيجان مشكل آفرين؛ Y) خود آكاهى هيجانى: (آموزش و معرفى هيجان، شناسايى و & & \\
\hline نام كذارى و برجسب زدن به احساسات، تمايز ميان هيجانات مختلف، شناسايى هيجان در حالت فيزيكى و روانشناختى، و عوامل & 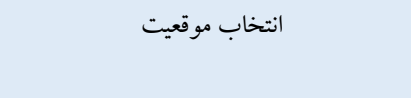 & r \\
\hline ارزيابى ميزان آسيبيذ يرى و مهارت هاى هيجانى اعضا: () خودارزيابى با هدف شناخت تجربههاى هيجانى خود؛ r) خودارزيابى & & \\
\hline 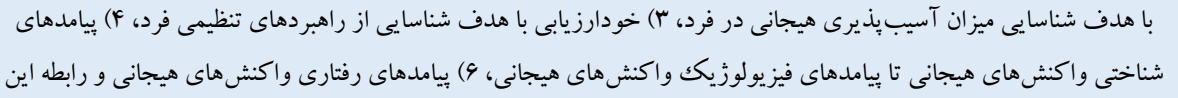 & 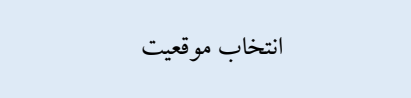 & $r$ \\
\hline 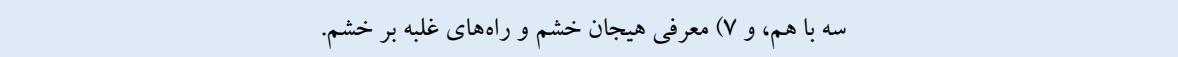 & & \\
\hline 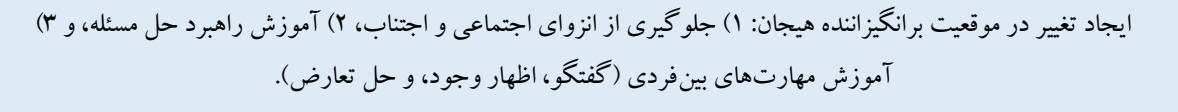 & 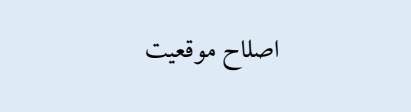 & $\varepsilon$ \\
\hline تغيير توجه: () متوقف كردن نشخوار فكرى و نخرانى و r) آموزش توجه. & كسترش توجه & $\circ$ \\
\hline تغيير ارزيابىهاى شناختى: () شناسايى ارزيابىهاى غلط و اثرات آنها روى حالتهاى هيجانى و r) آموزش راهبرد ارزيابى & 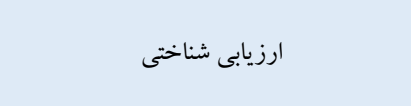 & 7 \\
\hline تغيير ييامدهاى رفتارى و فيزيولوزيكى هيجان: () شناسايى ميز ان و نحوه استفاده از راهبرد بازدارى و بررسى ييامهاى هيجانى آن؛ & & \\
\hline 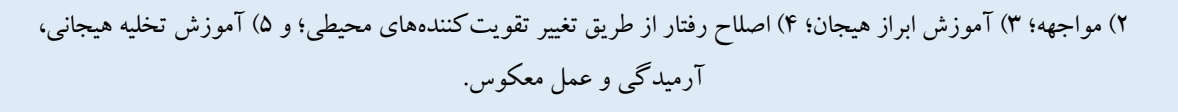 & ت تعديل باسخ & r \\
\hline 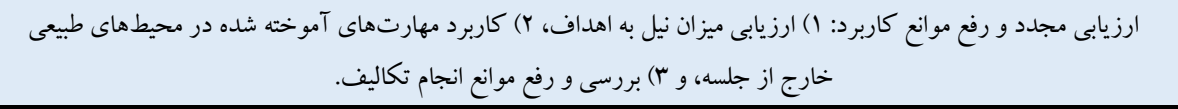 & 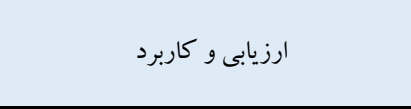 & $\wedge$ \\
\hline
\end{tabular}

آزادى عمـل براى تركى يزوهش در هر مرحلـهاى از اجرا، و اجراى

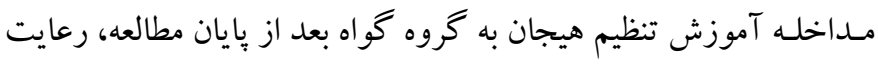

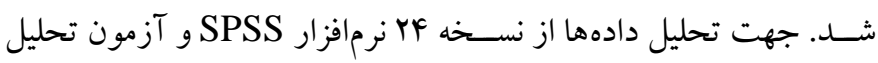

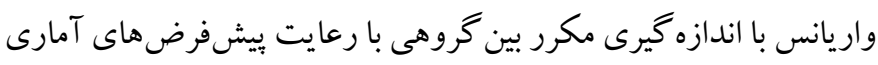
در سطح معنادارى ه•/ $\alpha=\mid$ استفاده شد.
د) روش اجر ا: بس از كســب مجوزهـاى مربوطسه در مرحلـه اجرا،

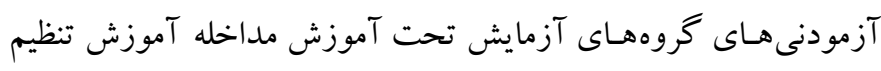

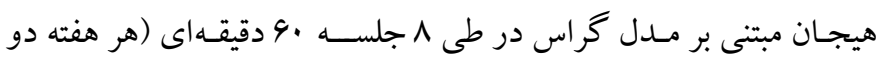

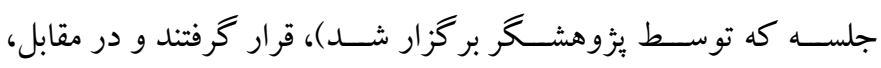

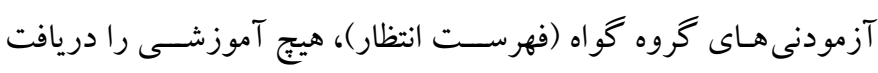
نكردنـــ. براى حـذف اثر دارونمـا، بِ از دوره دومهـاهـه، ارزيابى مجدد

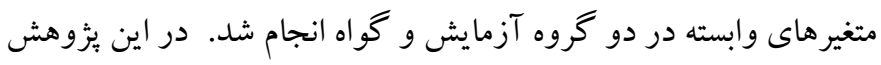

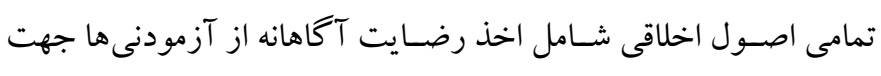

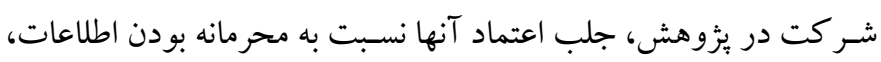


جدول r: شاخصهاى توصيفى عملكرد تحصيلى و سرزند

\begin{tabular}{|c|c|c|c|c|c|c|c|}
\hline \multicolumn{2}{|c|}{ بيغيرى } & \multicolumn{2}{|c|}{ ــ } & \multicolumn{2}{|c|}{ بيش آزمون } & \multirow{2}{*}{ متغير } & \multirow{2}{*}{ كروه } \\
\hline انحراف معيار & ميانكين & انحر اف معيار & ميانكين & انحراف معيار & ميانكين & & \\
\hline V/ATA & FA/VG & V/Orr & FN/AG & $V / V F I$ & FN/RD & خود كار آمديندارى & \multirow{6}{*}{ كواه } \\
\hline $9 / 099$ & $F r / q V$ & 91.41 & $\mid r / q 1$ & G/94F & $\mathrm{kr} / \mathrm{v}$. & تأثير ات هيجانى & \\
\hline 1/^94 & $1 V / 19$ & $1 / M M$ & $I V / F$. & $1 / 9 \cdot 0$ & $\mid \mathrm{V} / \cdot \Delta$ & فقدان مهار ييامد & \\
\hline$r / I I r$ & $11 / 11$ & $r / \cdot V \cdot$ & $11 / I F$ & T/MTr & $1 \cdot / \wedge \Delta$ & برنامهريزى & \\
\hline r/DrG & $10 / 9 V$ & $r / l \cdot V$ & $19 / 1 V$ & $r / F V V$ & $1 \Delta / \wedge \Delta$ & انخيزش & \\
\hline$F / .9 Y$ & س & F/TAT & $\mu r / Y$. & $f / \cdot F i$ & rr/v. & سرزندگى تحصيلى & \\
\hline 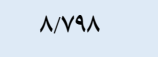 & $\Delta 1 / 94$ & N/N19 & $\Delta r / F q$ & $Q / \Delta Y \Lambda$ & $0 \cdot 19$ & خود كار آمديندارى & \multirow{6}{*}{ آزمايش } \\
\hline$\Delta / \Delta 9 q$ & KG/DF & $\Delta / \Delta \wedge \Delta$ & $F V / T \wedge$ & $\Delta / \Delta V Q$ & $f \Delta / 9$. & تأثير ات هيجانى & \\
\hline$r / \backslash \Lambda I$ & $|V / \Delta|$ & Y/YAV & $\mid \Lambda / F \Lambda$ & $r / .90$ & $19 / 0$. & فقدان مهار ييامد & \\
\hline $1 / A \cdot F$ & $11 / \mathrm{N} \mid$ & I/AVY & $\mid r / \Delta r$ & l/91F & $1 \cdot / 4$. & برنامهريزى & \\
\hline $1 / 901$ & $10 / 19$ & I/VOF & $19 / 90$ & $1 / \Delta \wedge 9$ & $\mid f / q$. & انخيزش & \\
\hline G/VOr & rY/rA & G/VVY & $\pi / \mu$. & $9 / \mathrm{VID}$ & $r \cdot / 9$. & سرزندگى تحصيلى & \\
\hline
\end{tabular}

قـبـل از اجـراى آزمـون تـحليـل واريـانس بـا انسـازه گيرى مكرر

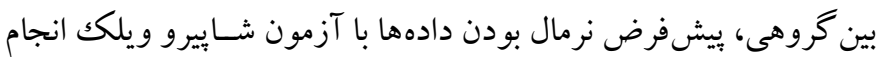

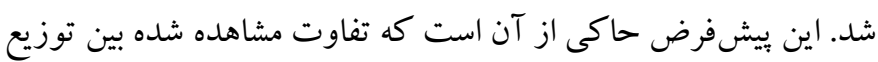

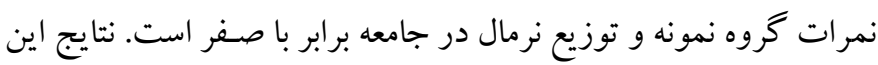

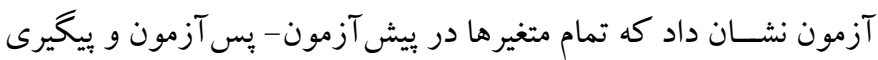
از توزيع نرمال بيروى مى كنند.
بر اســاس نتـايج جــدول ب، نمرات ميـانگين در همـه ابعـاد عملكرد

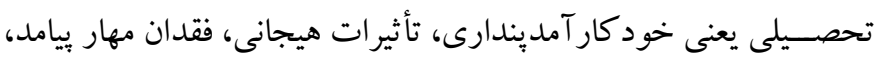

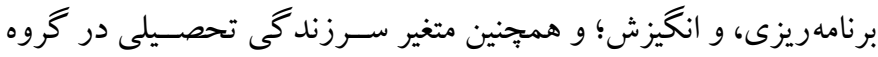

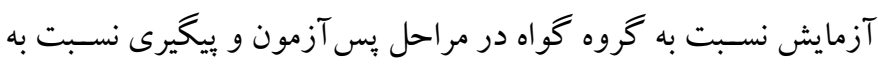
مرحله بيش آزمون افزايش يافته است.

جدول "َ: نتايج آزمون شإيرو-ويلكك براى بررسى نرمال بودن توزيع نمرات

\begin{tabular}{|c|c|c|c|c|c|c|}
\hline \multicolumn{2}{|c|}{ يِيَيرى } & \multicolumn{2}{|c|}{ هָ آزمون } & \multicolumn{2}{|c|}{ يِيش آزمون } & \multirow{2}{*}{ متغير } \\
\hline سطح معنادارى & شاييرو-ويلك & سطح معنادارى & شاييرو-ويلك & سطح معنادارى & شإِيرو -ويلك & \\
\hline - /4AT & ./Arq & $\cdot / \mu \cdot 4$ &.$/ 991$ &.$/ 9 \wedge 4$ & . / FAY & خود كار آمدى \\
\hline$\cdot / V 10$ &.$/ 991$ &.$/ 911$ & - /VOS &.$/ Q Y F$ & $\cdot / \Delta F A$ & تأثيرات هيجانى \\
\hline.$/ 9 \vee 9$ & $\cdot / 4 \mathrm{FV}$ &.$/ 91 f$ & $\cdot / \Delta \Delta \Lambda$ & $\cdot / \wedge \Delta Q$ & $\cdot 19 \cdot 4$ & فقدان مهار يیامد \\
\hline$\cdot / 1 / 9$ & .1944 & $\cdot / N 4$ & .1910 & . $/ F F$. & ./A9V & برنامهريزى \\
\hline.$/ 994$ & $\cdot / F Y I$ & . /99Y & . אro &.$/ 991$ & . /FrA & انغيزش \\
\hline . / TFY & $1 / \cdot{ }^{\prime}$ & .1949 & - $/ V F q$ & .1990 & $\cdot / \mathrm{VI}$. & سرزندگى تحصيلى \\
\hline
\end{tabular}

استفاده مى شود. در اين يُزوهش نتايج آزمون ماجلى بر ایى همه متغير هاى

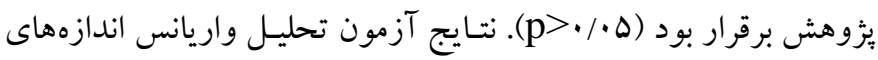

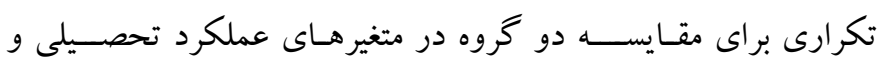

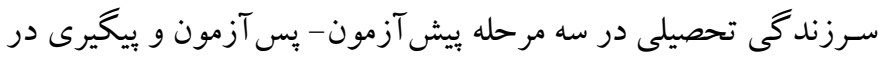
جدول F كزارش شده است.
همجنين بـه منظور بررسـى بيش فرض يكنو اختى كوواريـانس هـا يا

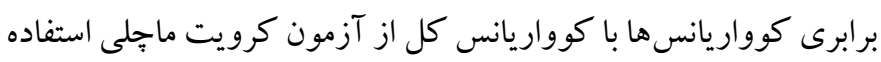

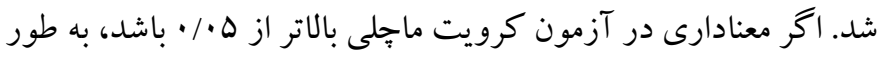

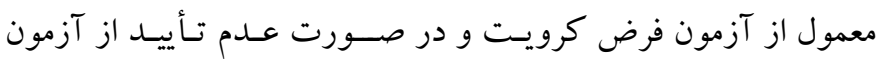

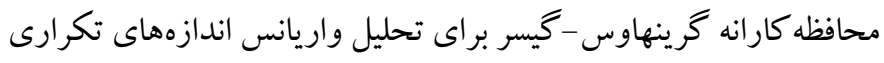


جدول ع: نتايج آزمون تحليل واريانس اندازههاى تكرارى جهت بررسى تفاوت كروهها در ابعاد عملكرد تحصيلى و سرزندكى تحصيلى در سه مرحله ييش آزمون، بـ آزمون

\begin{tabular}{|c|c|c|c|c|c|c|c|c|}
\hline \multicolumn{9}{|c|}{ و ويبكيرى } \\
\hline توان آمارى & ميزان تأثير & سطح معنادارى & $\mathbf{F}$ & ميانكين مجذورات & df & مجموع مجذورات & منبع تغيير & متغير \\
\hline 1 & $\cdot / 0 \cdot 1$ & $1 . .1$ & $r q / r \cdot 9$ & $14 / 991$ & $r$ & $r q / r 99$ & مراحل & \\
\hline - /119 & ו וr/ן & . $/ \mathrm{TVA}$ & $|/ T|$. & $r \Delta \Delta / 9 I V$ & 1 & $r \Delta \Delta / 91 V$ & كروهـا & خو دكار آمديندارى \\
\hline.$/ 999$ &.$/ Y \Delta 1$ &.$/ .1$ & Ir/VGV & $F / V V F$ & r & $9 / \Delta F \wedge$ & مراحل "* گروه & \\
\hline 1 &.$/ 419$ &.$/ .1$ & $r V / r Y q$ & $1 . / . r F$ & r & $r . / \%{ }_{1}$ & مراحل & \\
\hline$\cdot / T V \Delta$ & $.1 \% q$ & $\cdot / \mathrm{VI}$ & $1 / 949$ & $r I \cdot / r V \Lambda$ & 1 & $r I \cdot / r V A$ & أمرو & تأثيرات هيجانى \\
\hline 1 & $\cdot r \cdot v$ &.$/ .1$ & $19 / 199 \mathrm{~V}$ & G/AT & r & $\mid r / 49 F$ & مراحل * گروه & \\
\hline 1 & $\cdot / 0 \cdot 0$ &.$/ .1$ & rN/VaV & $1 r / 0.9$ & r & $\mathrm{rV} / .19$ & مراحل & \\
\hline$\cdot / v r$ & $\cdot / \cdot \Delta$ & $.19 \Delta \mathrm{F}$ & $\cdot / r \cdot 4$ & $r / F I I$ & 1 & $r / F \| l$ & كر & فقدان مهار بيامد \\
\hline 1 & $\cdot / T r F$ &.. .1 & $19 / . r 9$ & 9/9Y9 & r & Ir/ror & مراحل ** گروه & \\
\hline 1 & . $/ 9 T Y$ &.$/ .1$ & $90 / 491$ & $1 F / 9 Y A$ & r & $r Q / \Delta \Delta V$ & مراحل & \\
\hline -/IrF &.$/ .1 \mathrm{~V}$ & . Arr & $\cdot / 9 \Delta \Delta$ & V/ArF & 1 & V/ATF & كرو أها & برنامهريزى \\
\hline 1 & - / Faf & $\% . .1$ & rV/IFA & N/FAT & r & $19 / 990$ & مراحل ** گروه & \\
\hline 1 & . $/ \Delta+1$ &.$/ .1$ & $F Y / Q \Delta Q$ & $1 . / 9 \times 9$ & r & $r \mid / r \Delta V$ & مراحل & \\
\hline 1.9. & $\cdot / \cdot r$ & . NG & .1 .90 & $1 / 101$ & 1 & $1 / 101$ & كرونها & انغيزش \\
\hline 1 & / rar &.$/ .1$ & $r \cdot / 9 \cdot V$ & $\Delta / I T H$ & $r$ & $1 . / F+9$ & مراحل ** گروه & \\
\hline 1 & $. / 9 .$. &..$\cdot 1$ & $\Delta 9 / 994$ & rg/rVq & r & $\Delta T / V \Delta V$ & مراحل & \\
\hline / •Ar & $\cdot / \cdot \wedge$ & $\cdot / \Delta 91$ & . /rar & $\mathrm{TV} / \mathrm{TSO}$ & 1 & TV/YGD & كرومها & سرزندگى تحصيلى \\
\hline 1 & $\cdot / 4 \cdot 1$ & $\cdot / . .1$ & $r 9 / 19 \mathrm{~V}$ & $\mid r / 11 \wedge$ & r & TF/TrD & مراحل "* گروه & \\
\hline
\end{tabular}

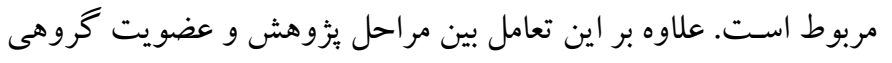

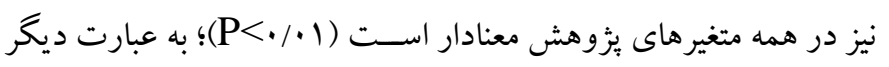

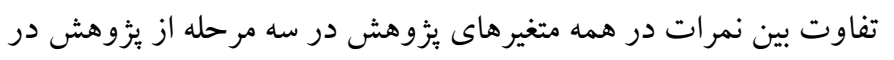

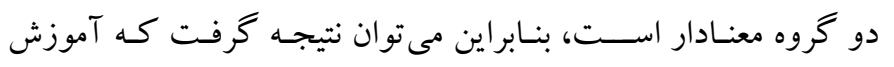

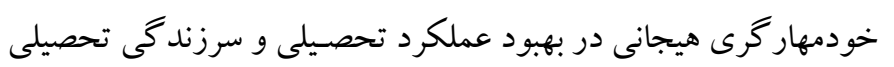

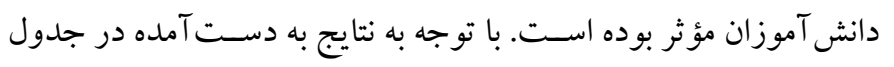

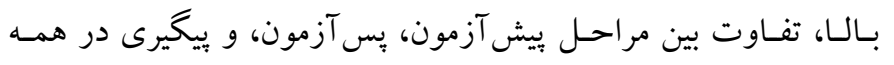

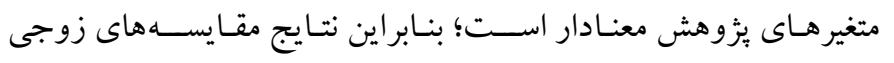

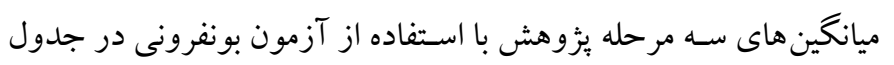

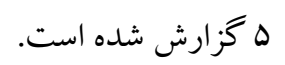

بر اسـاس يافتهاى به دســت آمده در جدول Fا، تفاوت بين نمرات

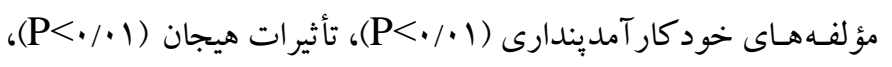

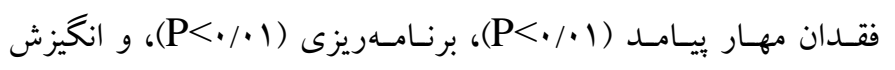

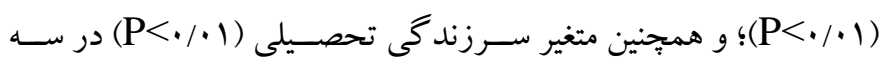

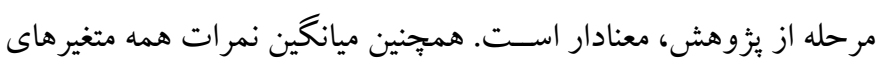

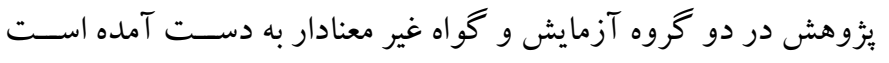

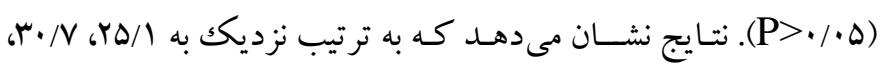

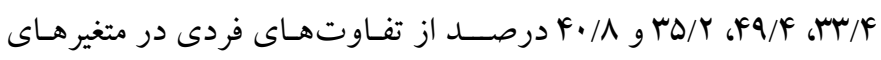

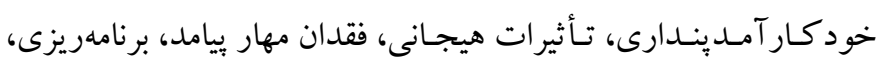

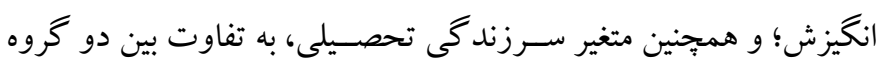

جدول 0: مقايسه زوجى ميانكين كروههاى خودمهار كرى هيجانى و كواه در سه مرحله يزوهش در متغيرهاى عملكرد تحصيلى و سرزندكى تحصيلى

\begin{tabular}{|c|c|c|c|c|c|}
\hline سطح معنادارى & خطاى استاندارد & اختلاف ميانكين & مرحله & متغير وابسته & كروه \\
\hline.$/ \cdot \Delta F$ & $\cdot / r \cdot \Lambda$ & $-\cdot / 010$ & يِش آزمون- يس آزمون & & \multirow{4}{*}{ كواه } \\
\hline (Ir/ & 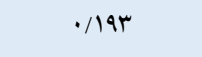 & $-\cdot / 4 \cdot 1$ & يِيش آزمون- ييگيرى & خو د كار آمديندارى & \\
\hline 1 & $\cdot / \mathrm{IVA}$ & $\cdot / \cdot V$ & پِ آزمون- يِيخيرى & & \\
\hline 1 & $\cdot / r$ rs & $-\cdot / r \mid$ & ييش آزمون- يس آزمون & تأثيرات هيجانى & \\
\hline
\end{tabular}




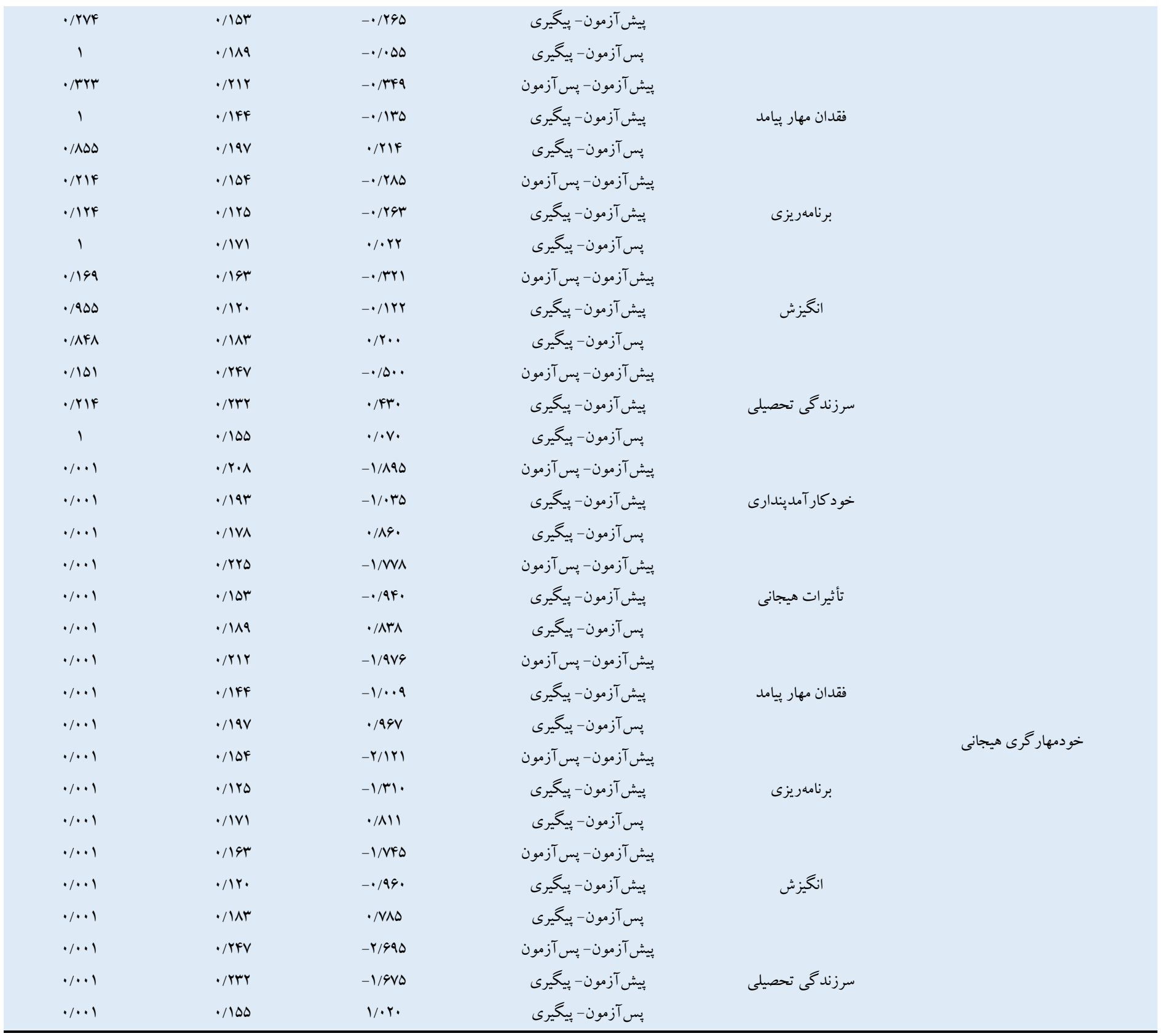

\section{بحث و نتيجه كيرى}

هدف مطالعه حاضـر تعيين اثربخشى خودمهار گرى هيجانى بر سرزندگى

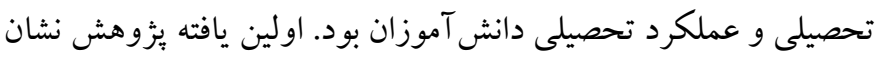

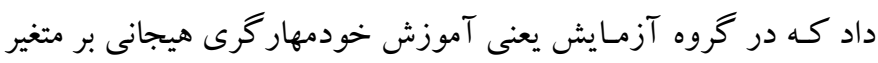

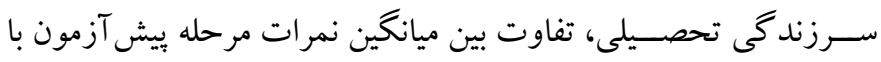

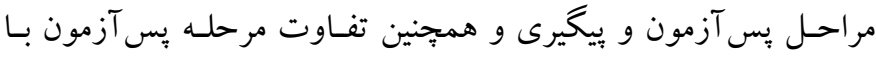

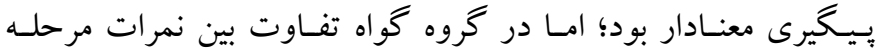

نتايج مقايسـهاى زوجى تفاوت ميانخينها در سـه مرحله آزمون در

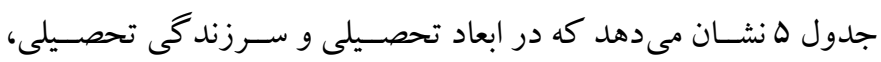

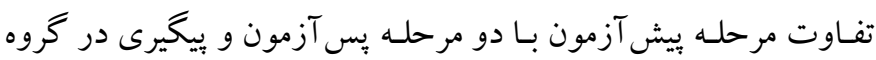

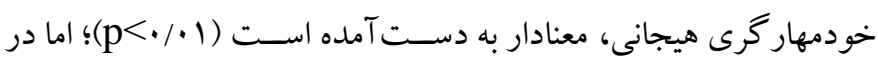

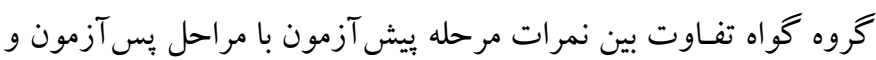

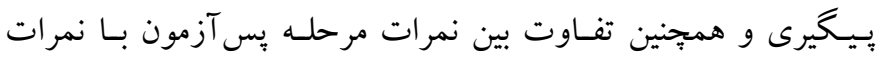

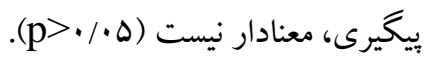


موقعيـت آموزش داده مىشــود (YY)؛ بنـابراين اســفــاده از راهبردهاى سازش يافته در تنظيم هيجان به نتايج مثبتى ختم مى شود و تنظيم هيجان و

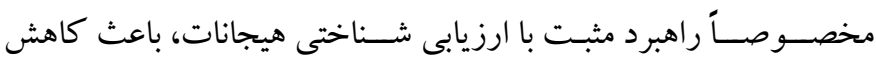
احسـاسات منفى، افزايش احساسات مثبت، و رفتار سازشيافته افراد و در

$$
\text { نتيجه سرزندگى مىشود. }
$$

ديخر يافته اين يزوهش نشان داد كه در گروه آزمايش يعنى آموزش خودمهار گرى هيجـانى بر متغير عملكرد تحصـيلى، تفاوت بين ميانگين

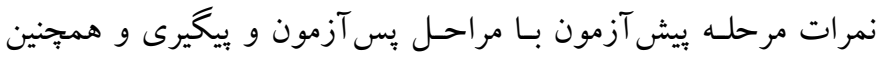

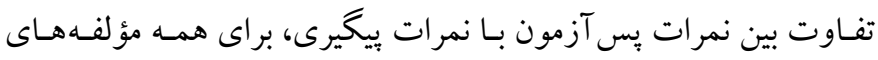

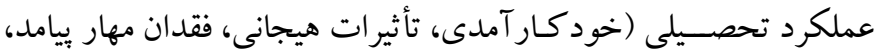

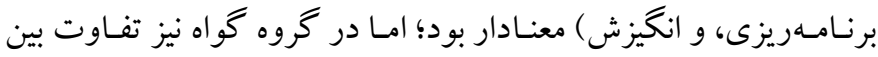

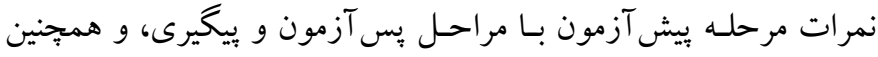

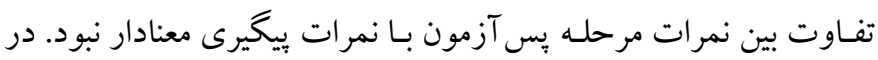

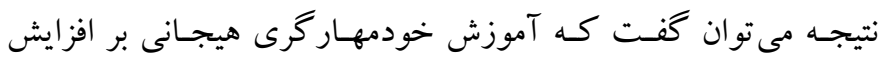

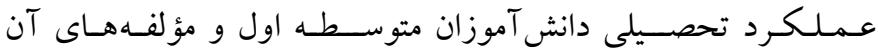

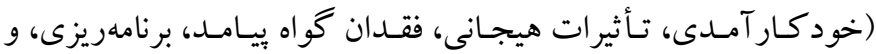

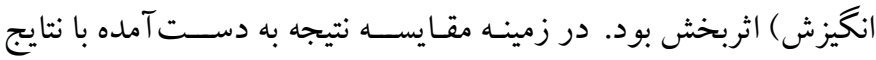

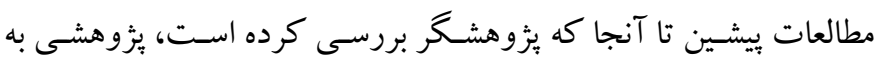
طور مستقيم انجام نشــده اسـت؛ اما به طور غيرمستقيم در همين راسـتا،

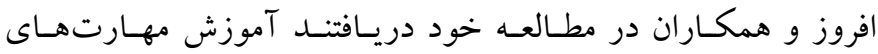
خودنظمبخشس بر افزايش و ارتقاى عملكرد تحصيلى دانش آموزان نابينا اثر كذار بود (YF). همجنين در مطالعهاى ديخر نشان داده شد كه آموزش

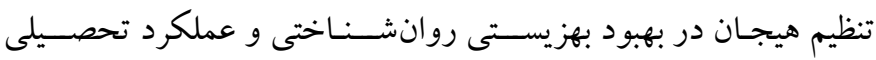

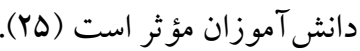
در تبيين نتيجـه بـه دســت آمـده مى توان كفـت تنظيم هيجـان و بـــ

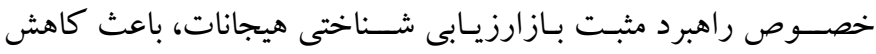
احسـاسـات منفى و افزايش احسـاسـات مثبت و رفتار سـازش يافته افراد

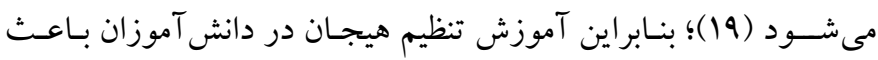

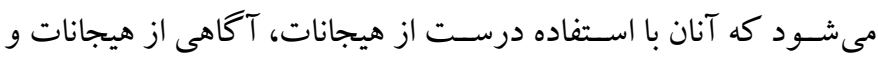
بذيرش آنها، و ابراز هيجانات به خصوص هيجانات مثبت در موقعيت هاى زنـدگى، احسـاسـات منفى خويش را كاهش دهند كه در نتيجه ميزان

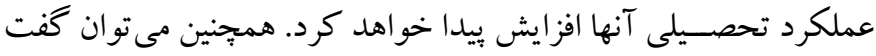

يُش آزمون با مراحل بس آزمون و بيگيرى، و همجنين تفاوت بين نمرات

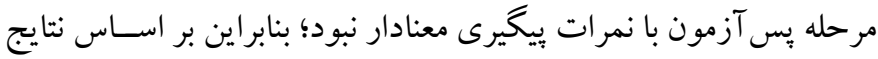

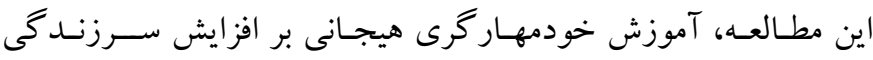

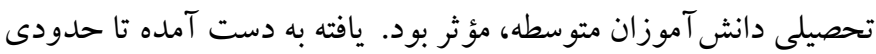
با نتايج سـاير مطالعات در اين زمينه به طور غيرمستقيم، همسـو اسـت. به به

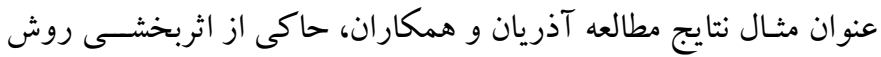

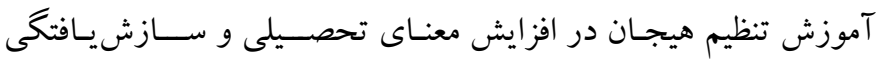

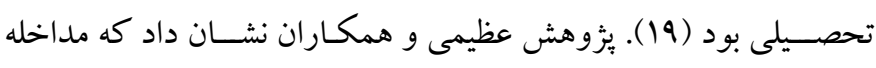

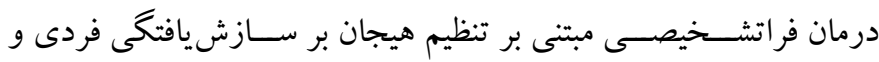
اجتماعى دانشـويان مؤثر اسـت (·Y). همجِنين عيسى بخش و همكاران در مطالعه خود دريافتند كه آموزش تنظيم هيجانى بر كاهش اضـطر دراب

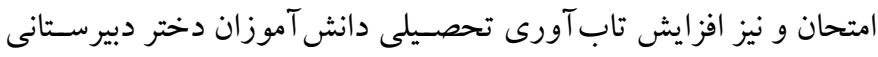
اثر خذار است (Y) (Y)

در تبيين يـافته فوق مى توان گفـت آموزش خودمهـار گرى هيجـانى

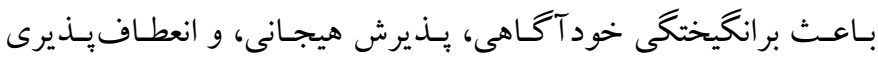
شـناختى فرد شــده و باعث بهبود توانيى فرد در اسـتفاده از راهبردهاى

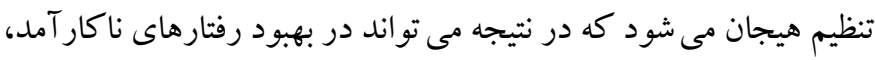

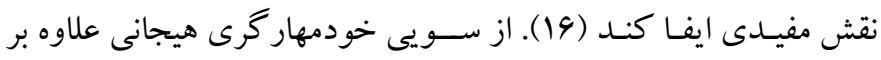

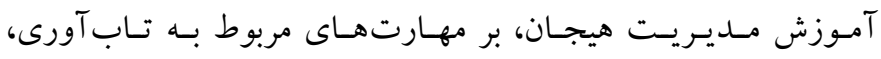

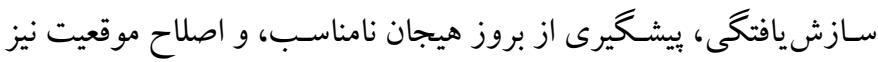

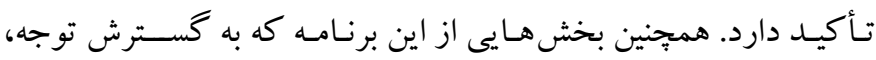

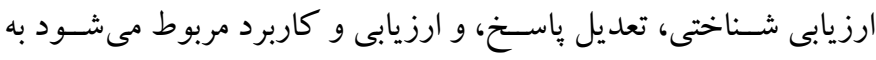

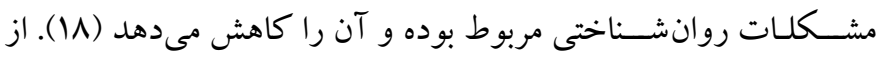

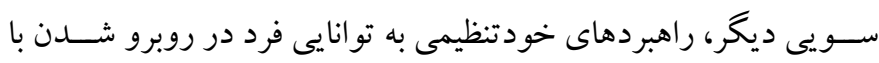

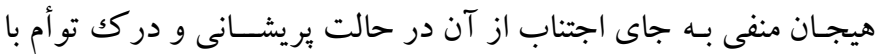
شـفقت جهت نيل به اهداف مهم، مربوط مى شــود (·Y). در اين راسـتا،

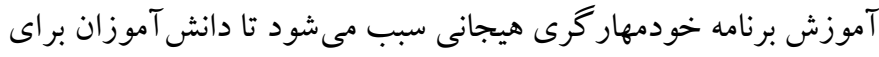
نظمبخشسى و مديريت رفتارهاى خويش، برنامه هدفمندى داشـته باشـند،

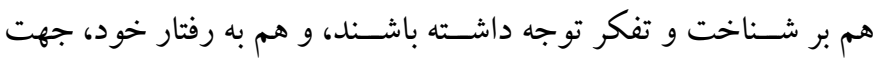
دهند. از آنجايى كه برنامه خودمهار گرى هيجانى بر تفكر منطقى و ابراز

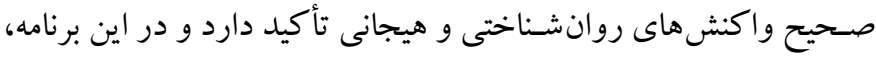
آكاهى از احسـاسـات و هيجانها و مهارت هاى در كك هيجان و انتخاب 
بـايــ در تعميم نتايج، با احتياط عمل كرد. همجينين محدوديت زمانى در زمـان بركزارى دوره بيكيرى براى بررســى اثرات بلنـدمـدت آموزش

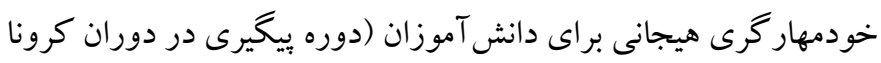
و به صسورت مجازى انجام شده است)، از ديخر محدوديت هاى بزّوهش حاضـر بود. ييشـنهاد مى شود كه برنامه آموزش خودمهار گرى هيجانى به عنو ان برنامه آموزشـى مكمل در كنار ســاير مهارت هاى آموزشــى در برنامههاى تقويتى مدارس و فوقبرنامه قرار گيرد. بيشــنهاد مى شـــود در

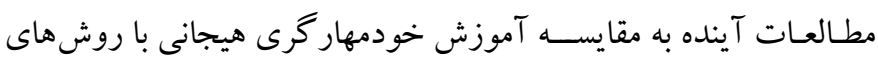
ديخر درمانى ازجمله درمان ذهن آكَاهى و تعهد و يذيرش برداخته شــود تا كارايى آن نسبت به روش هاى ديخر، بهتر روشن شود. همجنين جهت تعميميـذيرى نتـايج، يزوهش هـاى آتى روى هر دو جنس و نمونسهــاى بزرگت ترى از دانش آموزان، دانشجويان، و ساير گروههاى سنى، و مقاطع تحصيلى نيز مورد بررسى قرار كيرد.

ملاحظات اخلاقى

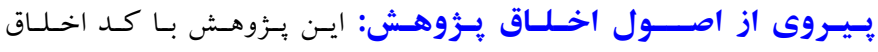

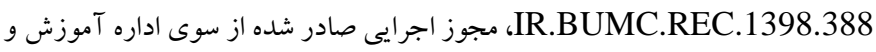

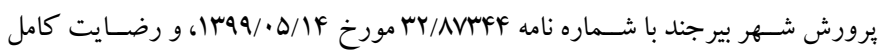
افر اد نمونه انجام شده است. حامى مالى: اين مقاله بدون حمايت مالى هيج گونه سـازمان يا مؤسسـهاى انجام شده است. نقش هر يكك از نويسـند كان: اين يُزوهش بر گرفته از رسـاله دكتراى آقاى سيروس

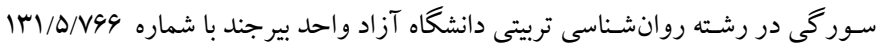
اسـت. همجِنين دكتر محمد حسين غنىفر و دكتر محمد رضـا اسدى به عنوان استادان راهنما، و دكتر قاسم آهى به عنوان استاد مشاور در اين مطالعه نقش داشتهاند. تضـاد منافع: نويسـندكان اعلام مى كنند در اين يثوهش، هيج كونه تضاد منافع وجود

نداشته است. تشـكر و قدردانى: بدين وسـيله از اسـتادان محترم راهنما و مشـاور، همكارى بسـيار خوب افراد نمونه، مسئولان اداره آموزش و برورش شهـرستان بير جند، و كادر ادارى و و

$$
\text { مربيان مدارس، تشكر و قدردانى مىشود. }
$$

كه خودمهار گرى هيجانى ييامدهاى ارزشـمندى در فر ايند ياد گيرى دارد و سـازش يافتكى و موفقيت در مدرسـه و اجتماع مسـتلزم اين اسـت كه دانش آموزان بـا اســتفـاده از فرايند خودمهار گرى هيجانى بتو انند درك خود را از دانستهها و شيوهاى كه بايد ياد بكيرند، بالا ببرند تا از اين طريق بتوانتـل بر شـــرايط نـاكوار بـه وجود آمـده، غلبـه كنتـد (Yr). برخى از

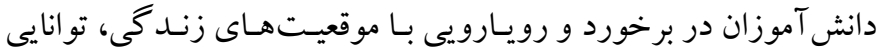
كمى براى مـــيريـت و تنظيم هيجـان دارند كه توانايى يايين در تجزيه و تفكيك هيجانات و ابراز سالم آن، سبب ناهنجارىها و مشكلاتى از قبيل اضــطر اب امتحان، ترك تحصــيل، داشـتن عملكرد ناموفق در تعاملات اجتماعى، برخاشـكرى، و خشـونت مى شـود (YO). دانش آموزان ضعيف اغلب از راهبردهاى ياد گيرى بى خبر هستند و از آنها در حل مسائل خود اســفــاده نمى كنــــ. اين كونـه دانش آموزان نـه تنها در ياد گيرى فعالانه در گير نمى شـوند، كه در به كاركيرى يردازش شـناختى نيز دجّار اشـكال هستند؛ بنابر اين به نظر مىرسد آشنا كردن دانش آموزان ضعيف با عوامل مؤثر در موفقيـت و شــكست، ســبـ افزايش انكيزه و بهبود عملكرد تـحصـــلى آنهـا مىشــود. همجيخين مى توان كفـت كـه در آموزش خودمهار گرى هيجانى، افر اد قادر مىشوند با شناخت و ارزيابى هيجانها و تـفسـيـر صـحـيـح از قـابليـتهـاى درونى خود كـه ريشــــه در خود كار آمديندارى آنها دارد، با خودارزيابى و كشف مهارت هاى مثبت و بـه كارگيرى آنها در زندگى واقعى و همجِنين به كار بردن راهبردهاى حـل مســـله، به توانايى بيشــتر و نيرومندترى در مواجهه با موقعيتهاى اضــطر ابزا و تنش آور برســـند. بنابر اين به نظر مىرســـ كه در مداخله حاضـر، به واسـطه آموزش و تلاش براى تغيير هيجانات منفى و جايخزين كردن افكـار كار آمد، ســطح خود كار آمديندارى افراد نمونه به ســطح مطلوبى ارتقا ييدا كرده اسـت. در مجموع يافته هاى اين مقاله مىتو اند در كنار يافته هاى ديخر مطالعات مرتبط انجام شده، به يك نظريه يا مدل، در راستاى ارتقاى سرزندگى و عملكرد تحصيلى، تبديل شود. از جمله محدوديت هاى بثزوهش حاضــر، خود كزارشـى بودن ابزار يثزوهش و محدود بودن نتايج به دانش آموزان يسر دوره متوسطه بود كه 


\section{References}

1. Mikaeili N, Afrooz G, Gholiezadeh L. The relationship of self-concept and academic burnout with academic performance of girl students. Journal of School Psychology. 2013; 1(4):90-103. [Persian]. [Link]

2. Chen W-W. The relations between perceived parenting styles and academic achievement in Hong Kong: The mediating role of students' goal orientations. Learning and Individual Differences. 2015; 37:48-54. [Link]

3. Kumar P, Singh U. Zuckerman's Alternative Five Factor Model and Risk Taking Behavior. IJIP. 2015; 3(1):122-128. [Link]

4. Yarahmadi Y, Naderi N, Akbari M, Yagoubi A. The effectiveness of academic resilience-based curriculum on academic delay and academic performance of students. Research in Teaching. 2019; 7(1):233-249. [Persian]. [Link]

5. Abbasi M, Ayadi N, Shafiee H. Role of social wellbeing and academic vitality in predicting the academic motivation in nursing students. Educ Strategy Med Sci. 2016; 8(6):49-54. [Persian]. [Link]

6. Comerford J, Batteson T, Tormey R. Academic buoyancy in second level schools: insights from Ireland. J Soc Behav Sci. 2015; 197(1):98-103. [Link]

7. Putwain DW, Connors L, Symes W, Douglas-Osborn E. Is academic buoyancy anything more than adaptive coping? Anxiety, Stress \& Coping. 2012; 25(3):349358. [Link]

8. Martin AJ, Colmar SH, Davey LA, Marsh HW. Longitudinal modelling of academic buoyancy and motivation: Do the 5Cs hold up over time? BRIT J EDUC PSYCHOL. 2010; 80(3):473-496. [Link]

9. Veselska Z, Geckova AM, Orosova O, Gajdosova B, van Dijk JP, Reijneveld SA. Self-esteem and resilience: The connection with risky behavior among adolescents. Addictive behaviors. 2009; 34(3):287291. [Link]

10. Lester D. Hopelessness in undergraduate students around the world: A review. J Affect Disord. 2013; 150(3):1204-8. [Link]

11. Finch D, Peacock M, Lazdowski D, Hwang M. Managing emotions: A case study exploring the relationship between experiential learning, emotions, and student performance. IJMIE. 2015; 13(1):23-36. [Link]

12. Miles SR, Tharp AT, Stanford M, Sharp C, Menefee D, Kent TA. Emotion dysregulation mediates the relationship between traumatic exposure and aggression in healthy young women. Pers Individ Differ. 2015; 76(2):222-227. [Link]

13. Hwang J. A processing model of emotion regulation: Insights from the attachment system. Georgia State University. 2006. [Link]

14. Morrish L, Rickard N, Chin TC, Vella-Brodrick DA. Emotion regulation in adolescent well-being and positive education. JHS. 2018; 19(5):1543-1564. [Link]

15. Gross JJ. Emotion regulation: Current status and future prospects. Psychological inquiry. 2015; 26(1):1-26. [Link]

16. Daly M, Baumeister R, Delaney L, MacLachlan M. Self-control and its relation to emotions and psychobiology: Evidence from a day reconstruction method study. J Behav Med. 2014; 37(1):81-93. [Link]

17. Khoshizamir S, Binesh M. The relationship between emotional cognitive adjustment strategies and emotional creativity with students' mental health. Journal of Research in Educational Systems. 2016; 10(33):85-100. [Persian]. [Link]

18. Piquero AR, Jennings WG, Diamond B, Farrington DP, Tremblay RE, Welsh BC, et al. A meta-analysis update on the effects of early family/parent training programs on antisocial behavior and delinquency. $\mathbf{J}$ Exp Criminol. 2016; 12(2):229-248. [Link]

19. Azarian R, Mahdian M, Jajarmi M. Comparison the effectiveness of academic buoyancy and emotion regulation training on academic meaning and academic adjustment. Journal of Research in Educational Systems. 2020; 14(2):38-38. [Persian]. [Link]

20. Azimi A, Omidi A, Shafiei E, Nademi A. The effectiveness of transdiagnostic, emotion- focused treatment for emotional regulation and individualsocial adjustment in female students. J Arak Uni Med Sci. 2018; 20(10):62-73. [Persian]. [Link]

21. Isabakhsh M, Seif AA, Dortaj F. Effect of emotional regulation on academic resilience and test anxiety of high school female students. Journal of Research in Educational Systems. 2018; 12(1):69-77. [Persian]. [Link]

22. Mehraban R, Livarjani S. Evaluation of the effectiveness of emotion regulation group training based on grass techniques on resilience, reactive aggression and emotional intelligence in first year high school students affiliated to Tabriz Quran Kindergarten. Scientific Journal Management System. 2018; 11(39):83-119. [Persian]. [Link] 
23. Rahmati F, Ghaffari E. Role of mindfulness, emotional regulation and perceived social support in the Prediction of academic achievement among second grade high school female student. Modern psychological research. 2015; 10(40):49-72. [Persian]. [Link]

24. Afrooz G, Moltafet G, Alborzi S, Gholamali Lavasani M, Hossein Khanzadeh A, Sadati SS. Effects of training self-regulation skills on academic performance among high school students with vision loss. J Exp Criminol. 2007; 7(2):169-186. [Persian]. [Link]

25. Djambazova-Popordanoska S. Implications of emotion regulation on young children's emotional wellbeing and educational achievement. Educational Review. 2016; 68(4):497-515. [Link]

26. Sadoughi M, Hesampour F. The mediating role of happiness in the relation between hope and academic self-Efficacy with academic buoyancy among students. Rooyesh. 2019; 8(9):21-30. [Persian]. [Link]

27. Delavar A. Research methodology in psychology and education. Tehran: Virayesh; 2015. [Persian]. [Link]

28. Dehghani Zadeh MH, Hosein-chari M. The academic vitality and perception of family communication patterns: the mediating role of self-efficacy. Studies in Learning \& Instruction. 2012; 4(2):21-48. [Persian]. [Link]

29. Moradi M, Cheraghi A. A study of causal relationship between perception of family communication patterns, perception of class structure, motivation and academic self-regulation and academic buoyancy in high school adolescents. Studies in Learning \& Instruction. 2014; 6(1):113-140. [Persian]. [Link]

30. Dortaje F. The check effect of mental simulations process and products on improving academic performance of students, structure and validate performance academic test. Tehran: Tarbiat Modares univ; 2004. [Persian]. [Link]

31. Karimi m, farahbakhsh k. Relationship between affective self-regulation and study skills with educational performance of students of is Isfahan University of medical science. Iranian Journal of Medical Education. 2012; 11(9):1149-1161. [Persian]. [Link]

32.Tangney JP, Baumeister RF, Boone AL. High selfcontrol predicts good adjustment, less pathology, better grades, and interpersonal success. Journal of personality. 2004; 72(2):271-324. [Link]

33. Ahmaadi Joybari M. The Relationship between Selfcontrol and Responsibility of the Sixth Grade Girl Elementary School Students (Case Study: Babolsar City). Journal of Psychology, Educational Sciences and Social Sciences. 2017; 1(2):63-70. [Link]

34.Gross JJ. Emotion regulation: taking stock and moving forward. Emotion. 2013; 13(3):359-365. [Link]

35.Ghaedniay jahromi A, Nori R, Hasani J, Farmani shahreza S. The effectiveness of group training of procedural emotion regulation strategies in cognitive coping of individuals suffering substance abuse. Research on Addiction. 2015; 8(31):71-90. [Persian]. [Link] 